Short communication

\title{
Detrimental effects detected in exfoliated buccal cells from anesthesiology medical residents occupationally exposed to inhalation anesthetics: An observational study
}

\author{
Mariana G. Braz ${ }^{\text {a,*, Kátina M. Souza }}{ }^{\text {a }}$, Lorena M.C. Lucio ${ }^{a}$, Giulia C.C. Di Renzo ${ }^{a}$, \\ Luciana M. Feliciano ${ }^{\mathrm{b}}$, João Paulo C. Marcondes ${ }^{\mathrm{b}}$, C.-Y. Oliver Chen ${ }^{\mathrm{c}}$, José Reinaldo C. Braz ${ }^{\mathrm{a}}$, \\ Leandro G. Braz ${ }^{\mathrm{a}}$

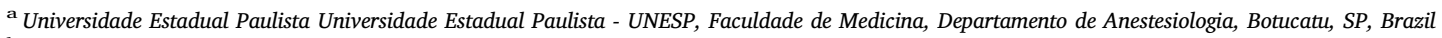 \\ ${ }^{\mathrm{b}}$ Universidade Estadual Paulista Universidade Estadual Paulista - UNESP, Instituto de Biociências, Departamento de Genética, Botucatu, SP, Brazil \\ ${ }^{\mathrm{c}}$ Jean Mayer USDA Human Nutrition Research Center on Aging, Tufts University, Boston, MA, USA
}

\section{A R T I C L E I N F O}

\section{Keywords:}

Occupational exposure

Anesthetic gases

Buccal mucosa

Genome instability

\begin{abstract}
A B S T R A C T
Operating room professionals are scarcely aware of their individual occupational exposure to waste anesthetic gases (WAGs). Medical residents spend several hours per day in operating rooms and consequently experience occupational exposure to WAGs. Considering that no studies have yet evaluated the potential toxicity in medical residents exposed to WAGs using the buccal micronucleus cytome (BMCyt) assay, this pioneering study aimed to compare the BMCyt assay markers, including DNA damage, cell proliferation, and cell death in the exfoliated buccal cells of surgery and anesthesiology residents occupationally exposed to WAGs. The study enrolled a total of 60 physicians, including internal medicine residents (unexposed group), and residents from surgery and anesthesiology programs who were occupationally exposed to sevoflurane, isoflurane and nitrous oxide. WAGs were measured, and the mean values were higher than the international recommendation. The anesthesiology residents (high exposure) showed statistically significant lower frequencies of basal cells, and statistically significant higher frequencies of micronuclei, karyorrhexis, pyknosis, and differentiated cells than did the unexposed group; karyolysis frequencies were significantly higher in anesthesiology residents than were those in the unexposed group or in surgical residents (low exposure). The findings suggest a genetic risk for young professionals exposed to WAGs at the beginning of their careers. Thus, exposure to high WAGs concentrations leads to impairment of the buccal cell proliferative potential, genomic instability and cell death, especially in anesthesiology residents, demonstrating an early impact on their health.
\end{abstract}

\section{Introduction}

The most important cause of waste anesthetic gases (WAGs) contamination in a surgical environment is the lack of a proper scavenging system in the operating rooms [1]. However, even if professionals are working in scavenged operating rooms, they are still exposed to trace concentrations of inhalation anesthetics, particularly during pediatric anesthesia [2]. Thus, several types of professionals are exposed daily to WAGs, and this exposure can have harmful effects on workers' health $[3,4]$. Although inhalation anesthetics have been commonly used for some decades in clinical practice, operating room professionals are scarcely aware of their individual occupational exposure to WAGs.

According to the National Institute of Occupational Safety and
Health (NIOSH) [5,6] the recommended exposure limit to minimize risk is $25 \mathrm{ppm}$ as the time-weighted average (TWA) for the anesthetic gas nitrous oxide and $2 \mathrm{ppm}$ for a one-hour ceiling for old halogenated anesthetics, such as halothane and enflurane. However, the exposure limit for most modern inhalation anesthetics (halogenated), such as isoflurane, sevoflurane and desflurane, remains an open question.

The potential of WAGs to induce systemic genetic damage has already been described $[7,8]$. However, these previous studies were performed in professionals exposed to an unmeasured mixture of anesthetic concentrations, including halothane, which is currently not in use.

Among several techniques for assessing DNA damage, the human buccal micronucleus (MN) cytome (BMCyt) assay has a low cost, is

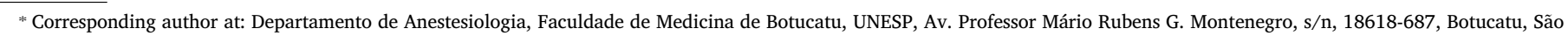
Paulo, Brazil.

E-mail addresses: mgbraz@fmb.unesp.br, mgbraz@hotmail.com (M.G. Braz). 
simple to perform, does not require cell culture and is minimally invasive [9]. This assay is a cytogenetic method for measuring genetic damage, cell proliferation and cell death in exfoliated buccal cells and has been widely used for biomonitoring of inhalation exposure [10]. In addition, buccal cells serve as one of the first barriers in direct contact with inhalation substances, such as WAGs. However, only two studies have applied this assay to evaluate the toxic effects of chronic exposure to WAGs $[7,11]$.

Anesthesiology and surgery residents spend several hours per day in operating rooms and consequently have occupational exposure to WAGs. Indeed, a few studies have reported genetic lesions, changes in redox status and increased pro-inflammatory cytokines in these young professionals exposed to WAGs $[12,13]$. However, no studies have yet evaluated cell toxicity in medical residents exposed to WAGs using the BMCyt assay.

Considering the novelty and importance of this subject, the current pilot study aimed to compare markers of DNA damage, cell proliferation, and cell death in exfoliated buccal cells from young physicians occupationally exposed to WAGs at the end of their anesthesia or surgery residency programs.

\section{Material and methods}

\subsection{Study design and occupational exposure}

After receiving approval from the Human Research Ethics Committee (38250114.3.0000.5411), and after obtaining written informed consent from all the participants, this observational study recruited medical residents from a Brazilian tertiary hospital as follows: 30 residents from internal medicine (unexposed group) and 30 residents from surgery $(n=16)$ and anesthesiology $(n=14)$ programs (exposed to the WAGs sevoflurane, isoflurane and nitrous oxide). A questionnaire was administered to all the individuals to obtain demographic data and lifestyle and medical history. The exposed group was age- and sex-matched with the unexposed group. The biological sampling was performed from 2013 to 2014. Current smokers, heavy drinkers [those who consumed more than one liter of light beverage or two cups of hard liquor per day for at least six years; [14], individuals who had chronic infectious or inflammatory diseases, and those who used medications, vitamins and/or antioxidant supplements, and those who had recently been exposed to radiation (within a month) were excluded from the study to avoid possible bias.

All the medical residents from the exposed group worked in all the 13 operating rooms in the hospital, of which half had a partial scavenging system and the other half had no active scavenging system, as previously described [15]. All the WAGs were measured (ppm) at real time in the medical resident's breathing zone during surgeries under inhalation anesthesia in all the operating rooms. The measurements were performed using a portable infrared analyzer (InfraRan 4gas anesthetic specific vapor, Wilks Enterprise, East Norwalk, CT), which was calibrated, as recommended by the manufacturer, prior to the measurements. TWA values (for nitrous oxide) and averages (for the halogenated anesthetics) were calculated and shown in ppm.

\subsection{Biological samples and the BMCyt assay}

The BMCyt assay was performed according to a previously described protocol [16] with slight modifications. Briefly, fresh exfoliated buccal cells were collected from both cheeks of the medical residents using a wooden spatula that was subsequently placed in a coded falcon tube containing cold saline solution. The tube was vortexed for detachment of the cells and then centrifuged. The supernatant was removed, and the cells were fixed with methanol-acetic acid solution. The pellet was suspended and used to prepare coded slides in duplicate per individual. Then, the slides were stained using the Feulgen-fast green method.
All the cell types and nuclear abnormalities from the buccal mucosa samples were determined as recommended [17] by blind analysis using an Olympus BX43 microscope at x 1000 magnification. One experienced person scored the slides and cells were scored using bright field, and cells containing $\mathrm{MN}$ were confirmed as being positive by examining the cells under fluorescence. The frequencies of the various cell types were scored per 1000 cells, while the frequencies of MN and nuclear buds were scored per 2000 differentiated cells.

\subsection{Statistical analysis}

The sample size was calculated based on a pilot study (MN marker) to provide $80 \%$ statistical power (type I error - $\alpha$ of 0.05 and a type II error $-\beta$ of 0.20 ) to detect a mean group difference of 0.4 and standard deviation of 0.55 . The demographic data (age and body mass index) were analyzed using an analysis of variance, and sex was analyzed using a chi-square test. A generalized linear model (Poisson regression or negative binomial) was used for the analyzed BMCyt parameters. The results are expressed as the means and standard deviations. Significance was set at $p<0.05$.

\section{Results}

Because the groups were matched, there were no significant differences regarding demographic data (Table 1). All the physicians were young adults (25-33 years of age) of both sexes. The anesthesiology residents spent approximately $60 \mathrm{~h}$ /week (high hours exposure), and surgery residents spent $18 \mathrm{~h}$ /week (low hours exposure) in the operating rooms. The exposure assessment demonstrated that trace concentrations were $155 \pm 138 \mathrm{ppm}$ for nitrous oxide, $9.8 \pm 9.0 \mathrm{ppm}$ for sevoflurane and $5.1 \pm 4.2 \mathrm{ppm}$ for isoflurane.

Table 2 shows the detrimental effects observed in the exfoliated buccal cells (BMCyt assay) from the evaluated physicians. The exposed anesthesiology residents showed lower basal cell frequencies and higher differentiated cells frequencies than the control group. MN frequency was increased in the anesthesiology residents compared with that in the unexposed residents $(p=0.038)$. Karyorrhexis (2.5-fold) and pyknosis (3.1-fold) were significantly increased in the anesthesiology residents compared with those in the control group. Despite the higher frequencies were observed in the residents from the anesthesiology field and to a lesser degree from the surgery field, there were no significant differences among the groups in nuclear buds, binucleated cells or condensed chromatin $(p>0.05)$. Karyolysis was found to be significantly higher in anesthesiology medical residents than that in unexposed residents (4.9- fold) and surgery residents (2-fold).

\section{Discussion}

This pilot study showed for the first time that medical residents occupationally exposed to WAGs, especially the anesthesiology residents, showed alterations in buccal cell regenerative potential, demonstrated by the reduced frequency of basal cells and increased MN formation and cell death biomarkers, which are related to genetic

Table 1

Demographic data.

\begin{tabular}{|c|c|c|c|}
\hline \multirow[t]{2}{*}{ Parameters } & \multirow{2}{*}{$\begin{array}{l}\text { Unexposed } \\
(\mathrm{n}=30)\end{array}$} & \multicolumn{2}{|l|}{ Exposed group } \\
\hline & & $\begin{array}{l}\text { Anesthesiology } \\
(\mathrm{n}=14)\end{array}$ & $\begin{array}{l}\text { Surgery } \\
(n=16)\end{array}$ \\
\hline Age (years) & $28.8 \pm 1.9$ & $28.9 \pm 1.8$ & $28.2 \pm 1.4$ \\
\hline Sex (male) & 18 & 9 & 9 \\
\hline Body mass index $\left(\mathrm{kg} / \mathrm{m}^{2}\right)$ & $24.7 \pm 3.9$ & $24.3 \pm 3.2$ & $24.9 \pm 4.4$ \\
\hline Duration of exposure (years) & - & $2.9 \pm 0.4$ & $3.2 \pm 0.5$ \\
\hline
\end{tabular}

Data expressed as means \pm standard deviation or number. $p>0.05$. 
Table 2

Buccal micronucleus cytome assay markers analyzed in medical residents.

\begin{tabular}{|c|c|c|c|c|}
\hline \multirow[t]{2}{*}{ Parameters } & \multirow{2}{*}{$\begin{array}{l}\text { Unexposed } \\
(n=30)\end{array}$} & \multicolumn{2}{|l|}{ Exposed group } & \multirow[t]{2}{*}{$p$-value } \\
\hline & & $\begin{array}{l}\text { Anesthesiology } \\
(\mathrm{n}=14)\end{array}$ & $\begin{array}{l}\text { Surgery } \\
(\mathrm{n}=16)\end{array}$ & \\
\hline Micronuclei & $0.3 \pm 0.6 \mathrm{a}$ & $0.7 \pm 1.1 \mathrm{~b}$ & $0.6 \pm 0.9 \mathrm{ab}$ & 0.038 \\
\hline Nuclear buds & $1.3 \pm 1.9$ & $1.7 \pm 2.5$ & $1.5 \pm 2.4$ & 0.5 \\
\hline $\begin{array}{c}\text { Binucleated } \\
\text { Cells }\end{array}$ & $9.3 \pm 6.7$ & $12.4 \pm 8.8$ & $13.1 \pm 5.2$ & 0.1 \\
\hline $\begin{array}{l}\text { Condensed } \\
\text { chromatin }\end{array}$ & $18.7 \pm 13.2$ & $33.3 \pm 30.7$ & $23.1 \pm 20.1$ & 0.1 \\
\hline Karyorrhexis & $22.4 \pm 16.1 \mathrm{a}$ & $55.1 \pm 37.7 b$ & $38.9 \pm 23.5 \mathrm{ab}$ & 0.001 \\
\hline Pyknosis & $3.1 \pm 4.7 \mathrm{a}$ & $9.6 \pm 9.7 b$ & $5.0 \pm 5.2 \mathrm{ab}$ & 0.03 \\
\hline Karyolysis & $5.1 \pm 4.3 \mathrm{a}$ & $24.9 \pm 23.4 \mathrm{~b}$ & $12.5 \pm 14.6 \mathrm{a}$ & 0.0009 \\
\hline Basal cells & $54 \pm 23 a$ & $31 \pm 13 b$ & $40 \pm 15 \mathrm{ab}$ & 0.001 \\
\hline $\begin{array}{l}\text { Differentiated } \\
\text { Cells }\end{array}$ & $946 \pm 23 a$ & $969 \pm 13 b$ & $960 \pm 15 a b$ & 0.0001 \\
\hline
\end{tabular}

Data (\%) expressed as means \pm standard deviation. The means followed by different letters are significantly different.

instability.

NIOSH provides a reference concerning adequate working conditions and suggests limiting trace concentrations of WAGs to reduce the occupational hazard $[5,6]$. In addition, any exposure to WAGs should be kept to the lowest practical level [18]. However, our results demonstrated that these values exceeded the NIOSH recommendations by more than 6-fold for nitrous oxide, 5 -fold for sevoflurane and 2.5-fold for isoflurane, which demonstrates high exposure conditions. Such exposure conditions together with the larger number of working hours spent in operating rooms most likely contributed to the detrimental effects observed in the exfoliated buccal cells from the exposed medical residents, particularly in those from the anesthesiology residents because they had greater exposure ( 3.3 times) to WAGs than did the surgery residents.

Our findings of low basal cell frequencies in the anesthesiology residents exposed to WAGs for three years are similar to those described in anesthesiologists exposed to WAGs for several years [11]. In fact, a previous study showed that the frequencies of this cell type were lower in patients with neurodegenerative disease than were those in healthy subjects [19]. The current findings suggest that occupational exposure to WAGs may alter the regenerative potential of epithelial tissue.

Despite the higher frequencies observed in the residents from the anesthesiology field and to a lesser degree from the surgery field, there were no statistically significant differences among the groups concerning binucleated cells, nuclear buds, or condensed chromatin. However, our findings demonstrated increased MN frequency in the anesthesiology medical residents, suggesting that exposure to high WAG levels even for a relatively short time induces chromosome damage, leading to genomic instability. Notably, two previous studies have reported a significant increase in buccal MN in health professionals chronically exposed to various WAGs $[7,11]$. In fact, a study that compared MN formation associated with occupational exposure to WAG levels that exceeded the NIOSH limits (high-level exposure) versus exposure within the limits (low-level exposure) showed that compared with the control group only anesthesiologists and anesthetic nurses from the high-level exposure group exhibited an increase in micronucleated lymphocytes [20]. Additionally, a meta-analysis showed a significant increase in MN frequency in lymphocytes of operating room personnel chronically exposed to anesthetics [21].

In addition to buccal MN, cell death parameters, including karyorrhexis and pyknosis, were significantly increased in the anesthesiology residents compared with those in unexposed residents. In fact, there is evidence supporting the association of specific cell types and nuclear anomalies with aging and neurodegenerative diseases [19,22]. Notably, our results concerning DNA damage and cell death endpoints in anesthesiology medical residents exposed to WAGs for three years are in accordance with evidence obtained in subjects after chronic exposure to modern halogenated anesthetics together with nitrous oxide gas [11]. Another anomaly that reflects cytotoxic effects, namely, karyolysis, was found to be significantly higher in anesthesiology residents than that in unexposed residents or surgery residents, possibly due to the long shift schedule in operating rooms without an adequate WAG scavenging system. Therefore, the increase in cell death parameters also provides guidance regarding the degree of WAG toxicity because the parameters are related to the defense mechanisms used to eliminate genetically damaged cells. We also must be aware that according to a recent study [23] a large inter-laboratory variability was found in classifying different cell types, such as basal cells, and nuclear anomalies (condensed chromatin, karyorrhexis, pyknosis and karyolysis) indicating the subjectivity in the interpretation of some of the BMCyt scoring criteria. According to these authors, further studies are needed to identify the relevant factors responsible for the intra- and inter-individual variability in cell types associated with cell differentiation and cell death frequencies to minimize their impact on the results of biomonitoring studies.

Thus, our study suggests that high occupational exposure to WAGs for a relatively short time changes the cellular kinetics/cell renewal/ structural profile of the buccal mucosa in exposed young medical residents, especially those from the anesthesiology field. Because DNA damage and cellular death are important events during carcinogenic processes, especially in early phases, the current study represents an important evaluation with respect to the detrimental health effects induced by WAGs exposure. Therefore, our findings show evidence of the deleterious effects of occupational exposure to WAGs and draw attention to the possible risks for young residents. Reduction of this exposure is urgent, and our findings reinforce the importance of adopting adequate measures to decrease anesthetic pollution, especially by improving WAG scavenging systems in operating rooms in developing countries.

In conclusion, this study indicates that exposure to WAGs induces chromosomal instability, cytotoxicity and proliferative changes in young adult anesthesiology medical residents, demonstrating an early impact on occupational health. However, further studies are required to confirm the findings of our study, which was conducted in a relatively small number of subjects, and to investigate the possible mechanism(s) by which occupational exposure to WAGs leads to buccal cell DNA damage and cell impairment.

\section{Declarations of interest}

None.

\section{Conflict of interest}

There are no conflict of interest.

\section{Acknowledgments}

This study was supported by the following grants: \#2013/05084-8 and \#2013/21130-0, São Paulo Research Foundation (FAPESP) and \#472453/2013-0, The National Council for Scientific and Technological Development (CNPq). MGB was granted a Research Productivity Fellowship (PQ-2) from CNPq. GCCDR was granted a scholarship from PIBIC-CNPq, and KMS and LMCL were granted a scholarship from the Coordination of Improvement for Higher Education Personnel (CAPES). The authors thank Dr. Lídia R. de Carvalho and Dr. José E. Corrente for the statistics advice.

\section{References}

[1] G. Wiesner, M. Harth, R. Szulc, W. Jurczyk, P. Sobczynski, K.H. Hoerauf, J. Hobbhahn, K. Taeger, A follow-up study on occupational exposure to inhaled 
anaesthetics in Eastern European surgeons and circulating nurses, Int. Arch. Occup. Environ. Health 74 (2001) 16-20.

[2] C. Byhahn, H.J. Wilke, K. Westpphal, Occupational exposure to volatile anaesthetics: epidemiology and approaches to reducing the problem, CNS Drugs 15 (2001) 197-215.

[3] R. Quansah, J.J. Jaakkola, Occupational exposures and adverse pregnancy outcomes among nurses: a systematic review and meta-analysis, J. Womens Health (Larchmt) 19 (2010) 1851-1862.

[4] T. Casale, T. Caciari, M.V. Rosati, P.A. Gioffrè, M.P. Schifano, A. Capozzella, B. Pimpinella, G. Tomei, F. Tomei, Anesthetic gases and occupationally exposed workers, Environ. Toxicol. Pharmacol. 37 (2014) 267-274.

[5] NIOSH, National Institute of Occupational Safety and Health, Criteria for a Recommended Standard: Occupational Exposure to Waste Anesthetic Gases and Vapors, Publication No. 77B140, U.S. Department of Health, Education, and Welfare, Public Health Service, Center for Disease Control, Cincinnati, OH, 1977.

[6] NIOSH, National Institute for Occupational Safety and Health, Waste Anesthetic Gases: Occupational Hazards in Hospitals, Publication n. 2007-151, U.S. Department of Health, Education, and Welfare, Public Health Service, Center for Disease Control, Cincinnati, OH, 2007.

[7] M. Chandrasekhar, P.V. Rekhadevi, N. Sailaja, M.F. Rahman, J.P. Reddy, M. Mahboob, P. Grover, Evaluation of genetic damage in operating room personnel exposed to anaesthetic gases, Mutagenesis 21 (2006) 249-254.

[8] A.A. El-Ebiary, A.A. Abuelfadl, N.I. Sarhan, M.M. Othman, Assessment of genotoxicity risk in operation room personnel by the alkaline comet assay, Hum. Exp. Toxicol. 32 (2013) 563-570.

[9] S. Bonassi, E. Coskun, M. Ceppi, Y.P. Lin, M. Ceppi, W.P. Chang, N. Holland, M. Kirsch-Volders, E. Zeiger, S. Ban, et al., The human micronucleus project on exfoliated buccal cells (HUMNXL): the role of life-style host factors, occupational exposures, health status, and assay protocol, Mutat. Res. 728 (2001) 88-97.

[10] C. Bolognesi, S. Knasmueller, A. Nersesyan, P. Thomas, M. Fenech, The HUMNxl scoring criteria for different cell types and nuclear anomalies in the buccal micronucleus cytome assay - an update and expanded photogallery, Mutat. Res. 753 (2013) 100-113.

[11] K.M. Souza, L.G. Braz, F.R. Nogueira, M.B. Souza, L.F. Bincoleto, A.G. Aun, J.E. Corrente, L.R. Carvalho, J.R. Braz, M.G. Braz, Occupational exposure to anesthetics leads to genomic instability, cytotoxicity and proliferative changes, Mutat. Res. 791 (2016) 42-48.

[12] E.R. Costa Paes, M.G. Braz, J.T. Lima, M.R. Gomes da Silva, L. Bentes de Sousa, E.S. Lima, M. Carvalho de Vasconcellos, J.R. Cerqueira Braz, DNA damage and antioxidant status in medical residents occupationally exposed to waste anesthetic gases, Acta Cir. Bras. 29 (2014) 280-286.

[13] M.M. Chaoul, J.R. Braz, L.M. Lucio, M.A. Golim, L.G. Braz, M.G. Braz, Does occupational exposure to anesthetic gases lead to increase of pro-inflammatory cytokines? Inflamm. Res. 64 (2015) 939-942.

[14] A.M. Gontijo, J.P. Marcondes, F.N. Elias, M.L. de Oliveira, R.O. de Lima, D.M. Salvadori, J.L. de Camargo, DNA damage in cytologically normal urothelial cells of patients with a history of urothelial cell carcinoma, Environ. Mol. Mutagen. 40 (2002) 190-199.

[15] L.G. Braz, J.R.C. Braz, G.A.S. Cavalcante, K.M. Souza, L.M.C. Lucio, M.G. Braz Comparison of waste anesthetic gases in operating rooms with or without an scavenging system in a Brazilian university Hospital, Rev. Bras. Anestesiol. 67 (2017) 516-520.

[16] P.E. Tolbert, C.M. Shy, J.W. Allen, Micronuclei and other nuclear anomalies in buccal smears: methods development, Mutat. Res. 271 (1992) 69-77.

[17] P. Thomas, N. Holland, C. Bolognesi, M. Kirsch-Volders, S. Bonassi, E. Zeiger, S. Knasmueller, M. Fenech, Buccal micronucleus cytome assay, Nat. Protoc. 4 (2009) 825-837.

[18] OSHA, Occupational Safety and Health Administration (US), Anesthetic Gases: Guidelines for Workplace Exposure, Washington, (2000).

[19] P. Thomas, J. Hecker, J. Faunt, M. Fenech, Buccal micronucleus cytome biomarkers may be associated with Alzheimer's disease, Mutagenesis 22 (2007) 371-379.

[20] G. Wiesner, K. Hoerauf, K. Schroegendorfer, P. Sobczynski, M. Harth, H.W. Ruediger, High-level, but not low-level, occupational exposure to inhaled anesthetics is associated with genotoxicity in the micronucleus assay, Anesth. Analg. 92 (2001) 118-122.

[21] P. Vodicka, L. Musak, G. Fiorito, V. Vymetalkova, L. Vodickova, A. Naccarati, DNA and chromosomal damage in medical workers exposed to anaesthetic gases assessed by the lymphocyte cytokinesis-block micronucleus (CBMN) assay. A critical review, Mutat. Res. 770 (2016) 26-34.

[22] P. Thomas, S. Harvey, T. Gruner, M. Fenech, The buccal cytome and micronucleus frequency is substantially altered in Down's syndrome and normal ageing compared to young healthy controls, Mutat. Res. 638 (2008) 37-47.

[23] C. Bolognesi, S. Knasmueller, A. Nersesyan, P. Roggieri, M. Ceppi, M. Bruzzone, E. Blaszczyk, D. Mielzynska-Svach, M. Milic, S. Bonassi, D. Benedetti, J. Da Silva, R. Toledo, D.M. Salvadori, H. Groot de Restrepo, M. Filipic, K. Hercog, A. Aktas, S. Burgaz, M. Kundi, T. Grummt, P. Thomas, M. Hor, M. Escudero-Fung, N. Holland, M. Fenech, Inter-laboratory consistency and variability in the buccal micronucleus cytome assay depends on biomarker scored and laboratory experience: results from the HUMNxl international inter-laboratory scoring exercise, Mutagenesis 32 (2017) $257-266$ 